\begin{tabular}{|c|c|}
\hline Title & $\begin{array}{l}\text { The heights and weights of Irish children from the post-war era to } \\
\text { the Celtic tiger }\end{array}$ \\
\hline Authors & $\begin{array}{l}\text { Perry, Ivan J.;Whelton, Helen; Harrington, Janas M.;Cousins, } \\
\text { Bernard }\end{array}$ \\
\hline Publication date & $2009-03$ \\
\hline Original Citation & $\begin{array}{l}\text { Perry I.J., Whelton H., Harrington J., Cousins B., 2009. The } \\
\text { heights and weights of Irish children from the post-war era to the } \\
\text { Celtic tiger. Journal of epidemiology and community health, 63(3), } \\
\text { pp.262-264. }\end{array}$ \\
\hline Type of publication & Article (peer-reviewed) \\
\hline $\begin{array}{l}\text { Link to publisher's } \\
\text { version }\end{array}$ & 10.1136/jech.2008.079236 \\
\hline Rights & (c) 2009 IJ Perry et al; licensee BMJ Group \\
\hline Download date & 2023-04-26 11:16:43 \\
\hline $\begin{array}{l}\text { Item downloaded } \\
\text { from }\end{array}$ & http://hdl.handle.net/10468/115 \\
\hline
\end{tabular}

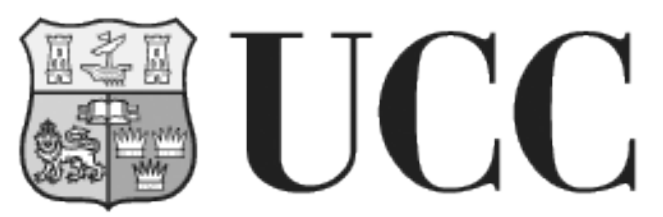

University College Cork, Ireland Coláiste na hOllscoile Corcaigh 


\section{JECH}

\section{The Heights and Weights of Irish Children from the Post-War Era to the Celtic Tiger}

Ivan J Perry, Helen Whelton, Janas Harrington and Bernard Cousins

$J$ Epidemiol Community Health published online 10 Feb 2009;

doi:10.1136/jech.2008.079236

Updated information and services can be found at:

http://jech.bmj.com/cgi/content/abstract/jech.2008.079236v1

\section{These include:}

Rapid responses You can respond to this article at:

http://jech.bmj.com/cgi/eletter-submit/jech.2008.079236v1 Email alerting $\begin{aligned} & \text { Receive free email alerts when new articles cite this article - sign up in the box at } \\ & \text { service }\end{aligned}$ the top right corner of the article

\section{Notes}

Online First contains unedited articles in manuscript form that have been peer reviewed and accepted for publication but have not yet appeared in the paper journal (edited, typeset versions may be posted when available prior to final publication). Online First articles are citable and establish publication priority; they are indexed by PubMed from initial publication. Citations to Online First articles must include the digital object identifier (DOIs) and date of initial publication.

To order reprints of this article go to:

http://journals.bmj.com/cgi/reprintform

To subscribe to Journal of Epidemiology and Community Health go to:

http://journals.bmj.com/subscriptions/ 


\title{
The heights and weights of Irish children from the post-war era to the Celtic tiger
}

\author{
I J Perry, ${ }^{1}$ H Whelton, ${ }^{2}$ J Harrington, ${ }^{1}$ B Cousins ${ }^{3}$
}

${ }^{1}$ Department of Epidemiology and Public Health, University College Cork; ${ }^{2}$ WHO Collaborating Centre for Oral Health Services Research, University College Cork; ${ }^{3}$ West Hill, Victoria Road, Douglas, Isle of Man

\section{Correspondence to:}

Professor I J Perry, Department of Epidemiology and Public Health, University College Cork, Room 2.50, Brookfield Health Sciences Complex, College Road, Cork, Republic of Ireland; i.perry@ucc.ie

Accepted 11 October 2008

\begin{abstract}
Background: Childhood obesity is a significant global health issue. National level data on long-term secular trends are relatively sparse.

Methods: Data were obtained from three large-scale surveys of school-aged children in Ireland involving measurements of height and weight in 1948, the 1970s and 2002.
\end{abstract}

Results: Significant increases in height and weight were observed in both boys and girls and in all age groups across the decades. The increases in weight were disproportionate to the trends in height. While boys aged 14 years were $23 \mathrm{~cm}$ taller 2002 than in 1948, their average weight was $61 \mathrm{~kg}$, compared with $37 \mathrm{~kg}$ in 1948, an increase of $24 \mathrm{~kg}$. A substantial proportion of the increase in weight is seen between the 1970s and 2002.

Conclusions: The data provide stark and compelling evidence on the evolution of the obesity epidemic in Irish children in tandem with the increase in economic prosperity.

During the 1990s, the Republic of Ireland experienced high annual rates of economic growth (the "Celtic tiger"), which reversed decades of economic underperformance and transformed the country from one of the poorest to one of the most affluent countries in Europe. In 2002, Ireland's gross domestic product (GDP) per capita was $€ 130.2$ billion, the second highest in Europe. ${ }^{1}$ In contrast, in the 1940s, the Irish economy was stagnant, the country did not benefit from the Marshall Plan or experience a post-war economic boom. In 1948, GDP per capita was $€ 0.432$ billion. In the ensuing decades, the Irish economy continued to underperform and, in the 1970s, GDP per capita was $€ 2.07$ billion, one of the lowest ranking in Europe. ${ }^{2}$ The effects of economic development on childhood growth have been documented in many countries worldwide. $^{3-6}$ Since 1947, overweight and obesity among Danish girls aged 6-8 years have increased by factors of 8 and 20 respectively. ${ }^{7}$ Increases were also seen in older children, with the rate of increase accelerating since 1975, accompanied by Denmark's increasing economic prosperity. We have examined trends in height, weight and body mass index (BMI) in representative samples of Irish children in $1946-48,{ }^{8}$ the $1970 s^{9}$ and $2002 .{ }^{10}{ }^{11}$ The findings are of interest, given the relatively unique historical pattern of economic development in Ireland in the twentieth century: prolonged stagnation followed by a rapid catch-up phase of high economic growth.

Heights and weights of children aged between 4 and 14 years in the Republic of Ireland were recorded in $1948(\mathrm{n}=14835)$, the 1970s
( $n=3509)$ and $2002(n=17518)$ as part of the Irish Nutrition Survey (1948), a cross-sectional study to develop growth charts for Irish children (the 1970s) and the North South Survey of Children's Oral Health (2002).

\section{RESULTS}

Data from 1948, the 1970s and 2002 show that children were taller and heavier in 2002 and that weight increased disproportionately to height (figs 1 and 2). On average, 14-year-old boys and girls were $23.1 \mathrm{~cm}$ and $15.6 \mathrm{~cm}$ taller, respectively, in 2002 than in 1948 (table 1).

More dramatic increases are seen in the weights of these children. The average weight of 14-yearold boys in 2002 was 65\% greater than in 1948 $(37.0 \mathrm{~kg}$ and $60.9 \mathrm{~kg}$ respectively), while that of girls also increased substantially(48\%) from $39.5 \mathrm{~kg}$ in 1948 to $58.7 \mathrm{~kg}$ in 2002. Mean BMI for 14-yearold boys and girls showed similar increases from $17 \mathrm{~kg} / \mathrm{m}^{2}$ and $18 \mathrm{~kg} / \mathrm{m}^{2}$, respectively, in 1948 to $21 \mathrm{~kg} / \mathrm{m}^{2}$ and $22 \mathrm{~kg} / \mathrm{m}^{2}$ in 2002 . Height increases appear to be more uniform across the decades than weight increases. In contrast, a substantial proportion of the increase in weight is seen between the 1970s and 2002. For example, among 14-year-old boys, average weight increased by $10 \mathrm{~kg}$ between 1948 and the 1970s, while there was on average a $14 \mathrm{~kg}$ increase between the 1970s and 2002. Similar trends can be seen in girls. These findings are also supported by international studies in which similar trends are seen since the mid-1970s. ${ }^{7}$

\section{CONCLUSION}

These data on trends in height and weight in Irish children during the latter half of the twentieth century highlight the profound impact of economic development and related societal changes on health. It is likely that Irish children in the midto late 1940s were undernourished given the lack of variety and choice of the habitual diet. However, given that Ireland was not subjected to food rationing during World War II or in the post-war era, the nutritional status of the Irish population at the time compared reasonably well with that of other European countries. While increases in the prevalence of overweight and obesity in childhood have been well documented worldwide since the 1980s, ${ }^{12-14}$ data from mid-century are sparse. However, similar trends over the period 1947 to 2003 are documented for Denmark,' including an escalation of overweight and obesity levels since the 1970s. While we must be cautious in drawing inferences based on three time points, there was evidence in our data of a similar acceleration in the rate of increase in childhood obesity in recent 


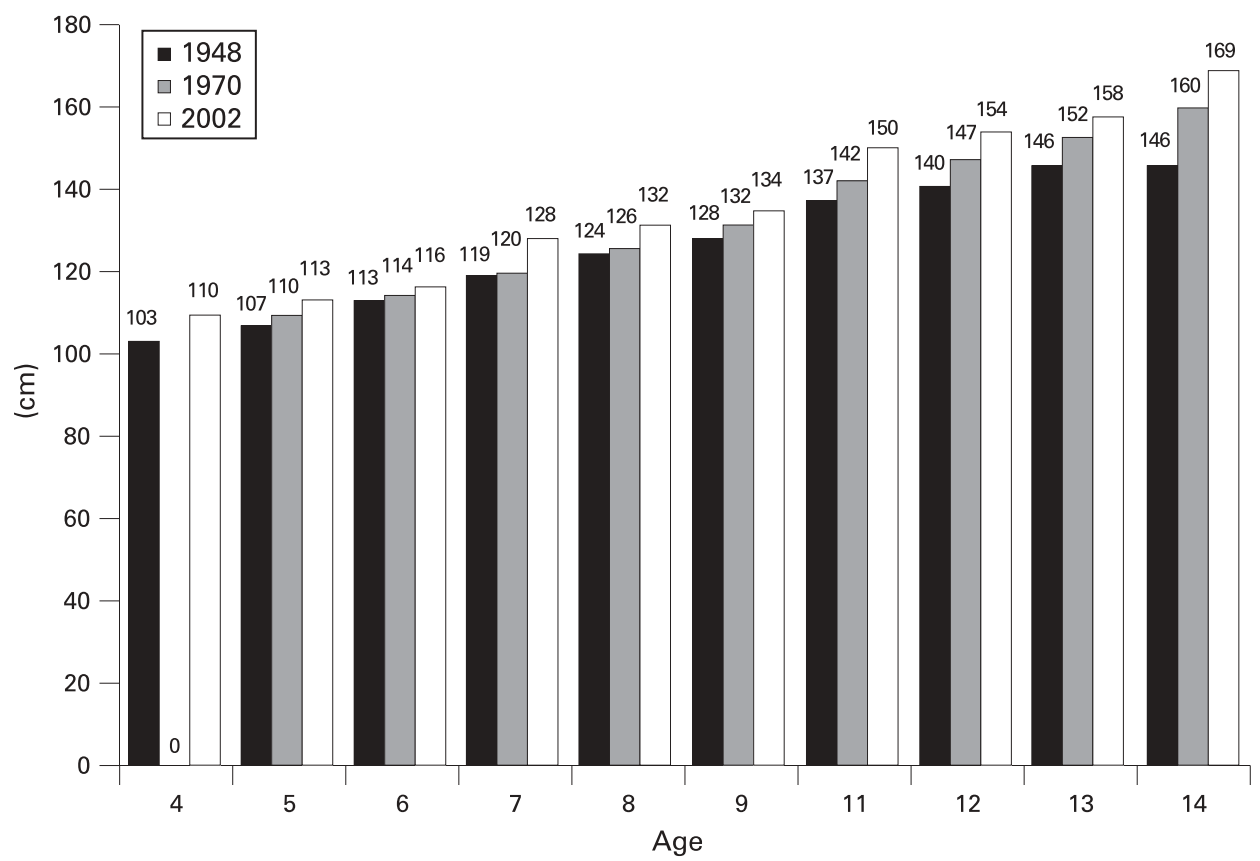

Figure 1 Mean height $(\mathrm{cm})$ in Irish boys between 1948 and 2002.

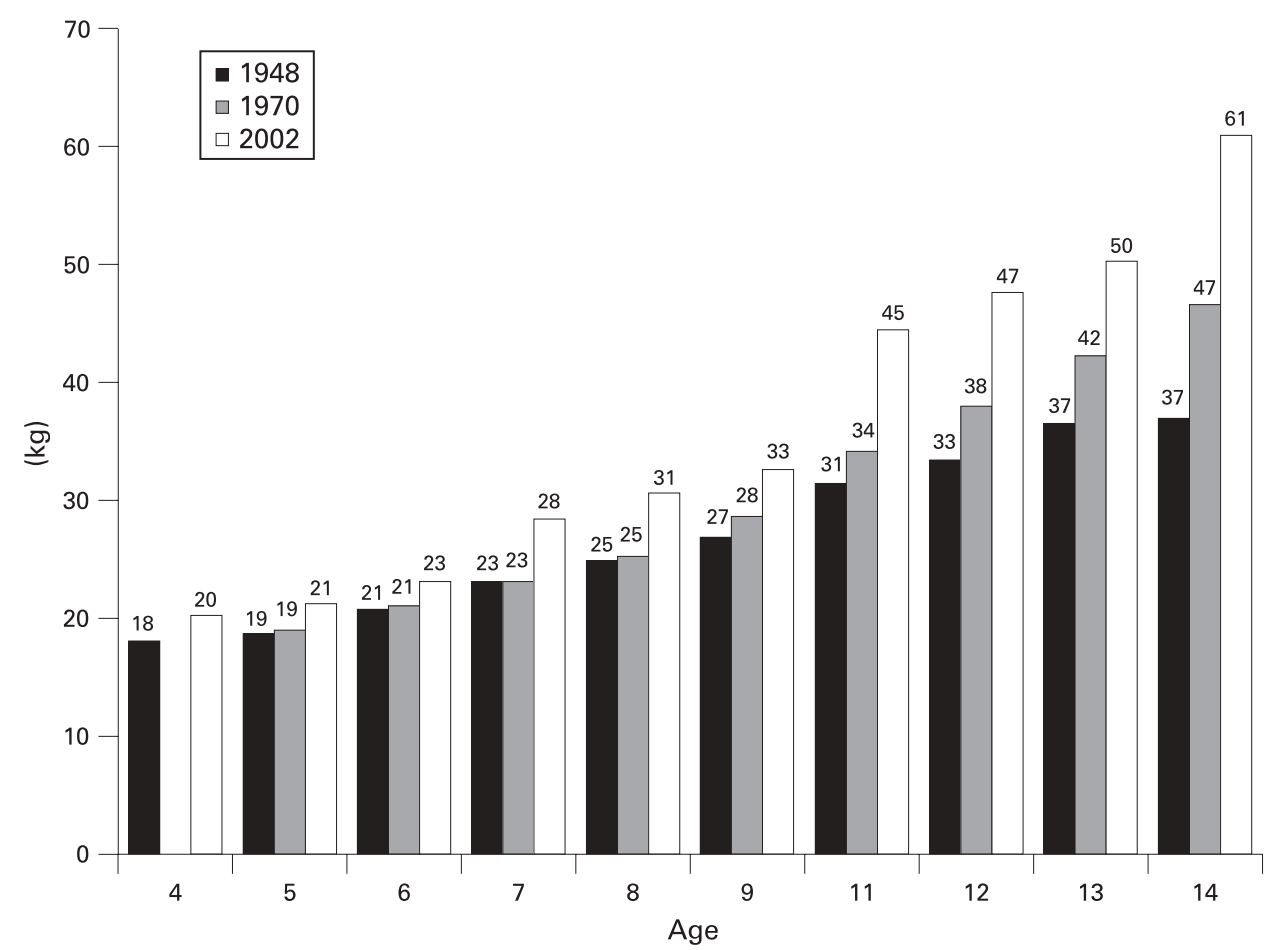

Figure 2 Mean weight $(\mathrm{kg})$ in Irish boys between 1948 and 2002.

decades. It is likely that the weight gain between the 1940s and the 1970s was beneficial; however, the major concern from a public health viewpoint is the rapid increase in weight disproportionate to height since the 1970s.

The relative intransigence of established obesity in adulthood provides a compelling argument for population-level primary prevention strategies. It is likely that the cost of the obesity epidemic, currently estimated at up to $8 \%$ of overall health budgets, will increase substantially. Over the coming decades, health systems worldwide face bankruptcy in the absence of a cohesive and multisectorial societal approach to the problem of overweight and obesity.

One can only speculate as to the effect that the current downturn in the Irish economy will have on the prevalence of obesity in Ireland. However, it is likely that, coupled with the increasing problem of food poverty and food insecurity, socioeconomic obesity gradients will be accentuated and the underlying high prevalence of overweight and obesity will not be reversed. 
Table 1 Mean height $(\mathrm{cm})$ and weight $(\mathrm{kg})$ for boys and girls in Ireland between 1948 and 2002

\begin{tabular}{|c|c|c|c|c|c|c|c|c|c|c|c|c|}
\hline \multirow{3}{*}{$\begin{array}{l}\text { Age } \\
\text { (years) }\end{array}$} & \multicolumn{6}{|c|}{ Height (cm) } & \multicolumn{6}{|c|}{ Weight (kg) } \\
\hline & \multicolumn{3}{|l|}{ Boys } & \multicolumn{3}{|l|}{ Girls } & \multicolumn{3}{|l|}{ Boys } & \multicolumn{3}{|l|}{ Girls } \\
\hline & 1948 & 1970 & 2002 & 1948 & 1970 & 2002 & 1948 & 1970 & 2002 & 1948 & 1970 & 2002 \\
\hline 4 & 103 & & 110 & 102 & & 109 & 18 & & 20 & 17 & & 20 \\
\hline 5 & 107 & 110 & 113 & 107 & 109 & 112 & 19 & 19 & 21 & 18 & 19 & 21 \\
\hline 6 & 113 & 114 & 116 & 112 & 113 & 116 & 21 & 21 & 23 & 19 & 21 & 22 \\
\hline 7 & 119 & 120 & 128 & 117 & 118 & 127 & 23 & 23 & 28 & 21 & 22 & 29 \\
\hline 8 & 124 & 126 & 132 & 121 & 124 & 131 & 25 & 25 & 31 & 23 & 25 & 31 \\
\hline 9 & 128 & 132 & 134 & 127 & 130 & 134 & 27 & 28 & 33 & 26 & 28 & 33 \\
\hline 11 & 137 & 142 & 150 & 136 & 141 & 151 & 31 & 34 & 45 & 30 & 34 & 47 \\
\hline 12 & 140 & 147 & 154 & 140 & 149 & 154 & 33 & 38 & 47 & 33 & 38 & 49 \\
\hline 13 & 146 & 152 & 158 & 145 & 154 & 157 & 37 & 42 & 50 & 37 & 43 & 52 \\
\hline 14 & 146 & 160 & 169 & 147 & 159 & 163 & 37 & 47 & 61 & 40 & 49 & 59 \\
\hline
\end{tabular}

\section{What is already known on this subject}

Clear secular trends of increasing height and weight in children linked to economic growth have been documented in many developed countries in recent decades. However, data from the middle of the twentieth century are sparse.

\section{What this study adds}

This study provides unique data from the Republic of Ireland, spanning a period of over 50 years and provides evidence of an accelerating trend in the prevalence of obesity form the 1970s, during the "Celtic tiger" era of economic growth. These findings add to the evidence that we face a global obesity crisis (global fattening) akin to global warming. Specifically, they highlight the need to align work addressing the global obesity epidemic with the broader climate change agenda. ${ }^{15}$ We are converting fossil fuels into relatively cheap calorie-dense food which is driving the obesity epidemic. We need to address our reliance on fossil fuels in food production and food transport and develop public policies to promote walking and cycling.

Competing interests: None.

\section{REFERENCES}

1. Central Statistics Office (CSO). That was then, this is now: change in Ireland 1948 to 1999. Cork: CSO, 2000.

2. Eurostat. The European Union and Russia: a statistical comparison. Luxembourg: Office for the Official Publication of the European Communities, 2007

3. Ben-Shlomo Y, Kuh D. A life course approach to chronic disease epidemiology: conceptual models, empirical challenges and interdisciplinary perspectives. Int J Epidemiol 2002;31:258-93.

4. Bhargava A, Jamison DT, Lau LJ, et al. Modeling the effects of health on economic growth. J Health Econ 2001;20:423-40.

5. Ranis G, Stewart F, Ramirez A. Economic growth and human development. World Dev 2000;28:197-219.

6. Roberts H,. Socioeconomic determinants of health: children, inequalities, and health. BMJ 1997;314:1122.

7. Pearson S, Olsen LW, Hansen B, et al. Increase in overweight and obesity amongst Copenhagen school children 1947-2003. Ugeskr Laeger 2005;167:158-62 (in Danish).

8. Department of Health. National nutrition survey, part 7, clinical survey. Dublin: Publication Office, 1952.

9. Hoey HM, Tanner JM, Cox LA. Clinical growth standards for Irish children. Acta Paediatr Scand Supp/ 1987;338:1-31.

10. Whelton H, Harrington J, Crowley E, et al. North South survey of children's height, weight and body mass index, 2002. Dublin: Department of Health and Children, 2006.

11. Whelton H, Harrington J, Crowley E, et al. Prevalence of overweight and obesity on the island of Ireland: results from the North South survey of children's height, weight and body mass index, 2002. BMC Public Health 2007; DOl: 10.1186/1471-2458-7-187.

12. Livingstone B. Childhood obesity in Europe: a growing concern. Public Health Nutr 2001:4:109-16.

13. Luo J, Hu F. Time trends of obesity in pre-school children in China from 1989 to 1997. Int J Obes 2002;26:553-8.

14. Tremblay M, Katzmarzyk P, Willms J. Temporal trends in overweight and obesity in Canada, 1981-1996. Int J Obes 2002;26:538-43.

15. Woodcock J, Banister D, Edwards $P$, et al. Energy and transport. Lancet 2007;370:1078-88. 